\title{
Sex- and brain region-specific acceleration of $\beta$-amyloidogenesis following behavioral stress in a mouse model of Alzheimer's disease
}

\author{
Latha Devi ${ }^{1}$, Melissa J Alldred ${ }^{1,2}$, Stephen D Ginsberg ${ }^{1,2,3}$, Masuo Ohno ${ }^{1,2^{*}}$
}

\begin{abstract}
Background: It is hypothesized that complex interactions between multiple environmental factors and genetic factors are implicated in sporadic Alzheimer's disease (AD); however, the underlying mechanisms are poorly understood. Importantly, recent evidence reveals that expression and activity levels of the $\beta$-site APP cleaving enzyme 1 (BACE1), which initiates amyloid- $\beta$ (A $\beta$ ) production, are elevated in AD brains. In this study, we investigated a molecular mechanism by which sex and stress interactions may accelerate $\beta$-amyloidogenesis and contribute to sporadic AD.

Results: We applied 5-day restraint stress (6 h/day) to the male and female 5XFAD transgenic mouse model of AD at the pre-pathological stage of disease, which showed little amyloid deposition under non-stressed control conditions. Exposure to the relatively brief behavioral stress increased levels of neurotoxic A 42 peptides, the $\beta$-secretase-cleaved C-terminal fragment (C99) and plaque burden in the hippocampus of female 5XFAD mice but not in that of male 5XFAD mice. In contrast, significant changes in the parameters of $\beta$-amyloidosis were not observed in the cerebral cortex of stressed male or female 5XFAD mice. We found that this sex- and brain region-specific acceleration of $\beta$-amyloidosis was accounted for by elevations in BACE1 and APP levels in response to adverse stress. Furthermore, not only BACE1 mRNA but also phosphorylation of the translation initiation factor elF2 $\alpha$ (a proposed mediator of the post-transcriptional upregulation of BACE1) was elevated in the hippocampus of stressed female 5XFAD mice.

Conclusions: Our results suggest that the higher prevalence of sporadic AD in women may be attributable to the vulnerability of female brains (especially, the hippocampus) to stressful events, which alter APP processing to favor the $\beta$-amyloidogenesis through the transcriptional and translational upregulation of BACE1 combined with elevations in its substrate APP.
\end{abstract}

\section{Background}

Alzheimer's disease (AD) is a progressive neurodegenerative disorder and the most common cause of dementia in the elderly. One of the hallmark pathologies of $\mathrm{AD}$ is the senile plaque that is constituted of amyloid- $\beta$ $(A \beta)$ peptides. Although mutations in three different genes favoring the overproduction of $A \beta$ are known to cause early-onset familial AD (FAD) [1,2], the etiology of sporadic $\mathrm{AD}$ that accounts for the majority of $\mathrm{AD}$ cases remains unclear. It is hypothesized that complex

\footnotetext{
* Correspondence: mohno@nki.rfmh.org

${ }^{1}$ Center for Dementia Research, Nathan Kline Institute, Orangeburg, New York 10962, USA

Full list of author information is available at the end of the article
}

interactions between the genetic background and various environmental factors underlie sporadic AD [3,4] and a stressful lifestyle may represent one of the important risk factors for AD [5]. Elderly individuals prone to psychological distress are more likely to develop AD than those not prone to distress, and this trait is also associated with a more rapid progression of disease [6,7]. Consistent with the clinical observations, recent studies demonstrated that exposure to adverse behavioral stress accelerates the development of amyloid pathology and worsens memory decline in transgenic mouse models of AD [8-11], although the underlying molecular mechanisms have not been investigated in detail. 
Meanwhile, it is also known that women have a higher risk of developing AD than do men. Although the longevity effect might be a factor in the preponderance of women with $\mathrm{AD}$, the sex difference in $\mathrm{AD}$ prevalence remains even after age adjustment [12-14]. Interestingly, not only the sex but also the brain region represents a determinant of neuronal responses to stressful experience. For example, the hippocampus is a structure highly sensitive to stressor and is enriched with glucocorticoid receptors [15]. Furthermore, opposite effects of stress on hippocampal functions have been reported; an acute stressful event facilitates learning and increases dendritic spine density in male rats, whereas learning and spine density deteriorate after exposure to the same stressor in female rats [16-18]. Therefore, it is important to determine whether and how gender and adverse stress may interact to modify disease progression in different brain regions of AD transgenic mice.

The $\beta$-cleavage of amyloid precursor protein (APP) by BACE1 ( $\beta$-site APP cleaving enzyme 1$)$ initiates the generation of neurotoxic $A \beta$ peptides. Notably, evidence is accumulating that increased levels of cerebral BACE1 and/or APP expression may be crucial contributing factors in developing sporadic AD [19-22]. In this study, we tested the hypothesis that behavioral stress may trigger the upregulation of BACE1 and/or APP, which may lead to differential acceleration of $\beta$-amyloidogenesis in the hippocampus and cerebral cortex of male and female subjects. Specifically, 5XFAD transgenic model mice at 3 months of age, which exhibit little or only faint amyloid pathology under normal conditions [23], were exposed to 5-day restraint stress, and we compared levels of BACE1, APP, its $\beta$-cleavage products and plaque burden between stressed and non-stressed subjects. We clearly demonstrate that the hippocampus of female 5XFAD mice shows the dramatic acceleration of $\beta$-amyloidogenesis with significantly elevated levels of both BACE1 and APP expression following the relatively brief stress treatment, providing a molecular basis for the higher prevalence and incidence of sporadic AD in women. Furthermore, our results also suggest that not only transcriptional but also translational mechanisms through phosphorylation of eukaryotic initiation factor$2 \alpha($ IF $2 \alpha)$ may underlie BACE1 elevation associated with adverse stress during AD progression.

\section{Results}

Behavioral stress accelerates $A \beta$ accumulation in 5XFAD mice in a sex- and brain region-dependent manner

To examine the effects of adverse behavioral stress on the pathogenesis of AD, male and female 5XFAD mice at 3 months of age, which develop little or only slight amyloid deposition under normal conditions [23], were subjected to 5 -day restraint stress $(6 \mathrm{~h} /$ day $)$. Twenty-four hours

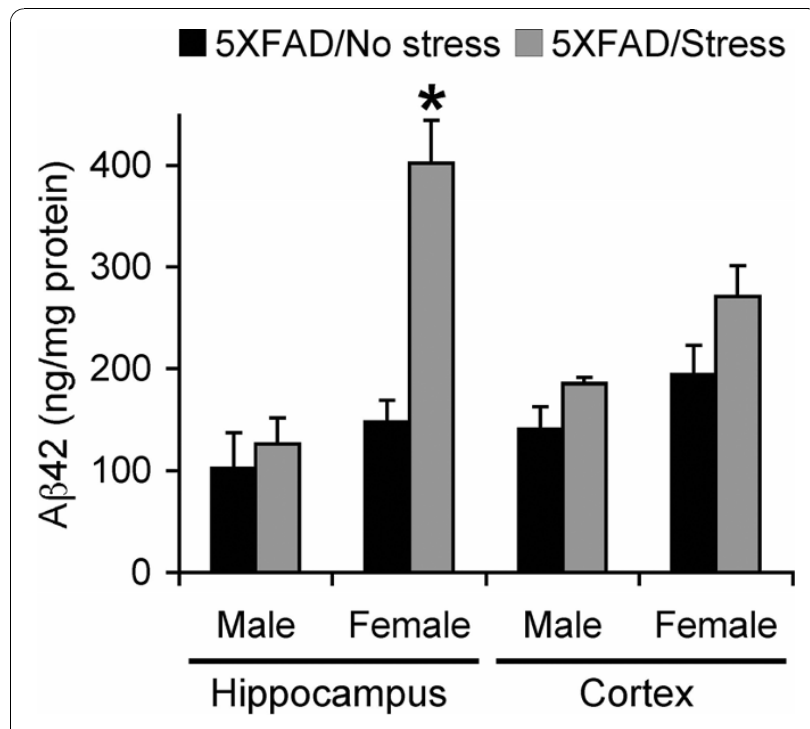

Figure 1 Effects of behavioral stress on $A \beta 42$ levels in the hippocampus and cerebral cortex of 5XFAD mice. Male and female mice were exposed to restraint stress for $6 \mathrm{~h}$ per day during 5 consecutive days and were sacrificed for analysis $24 \mathrm{~h}$ after the last stress treatment. Levels of total $A \beta 42$ were quantified by sandwich ELISA of guanidine extracts of hippocampal and cortical samples and expressed in nanograms per milligram of total protein ( $n=5-8$ mice per group). Note that A $\beta 42$ levels are increased specifically in the hippocampus of stressed female 5XFAD mice as compared with non-stressed controls $\left({ }^{*} p<0.05\right)$. All data are presented as mean \pm SEM.

after the cessation of stress treatments, we first performed sandwich ELISA to compare $A \beta$ levels between stressed and non-stressed 5XFAD mouse brains (Figure 1). The hippocampal and cortical samples were collected separately from male and female 5XFAD mice. The 5-day restraint stress significantly increased $A \beta 42$ levels only in the hippocampus of female 5XFAD mice $[F$ $(1,14)=29.00, p<0.0001]$, while the other three groups of 5XFAD brain samples showed no significant difference in $A \beta 42$ levels between stressed and non-stressed subjects (Figure 1).

To test whether the ELISA measurements of $A \beta 42$ reflected the acceleration of amyloid plaque formation, we conducted $A \beta$ immunostaining using separate groups of male and female 5XFAD mice with or without stress treatments (Figure 2). Little or no amyloid deposition was found in the hippocampus of non-stressed male (Figure 2A) or female (Figure 2D) 5XFAD control mice. Importantly, plaque load, as measured by percentage area occupied by $A \beta$ deposits, was significantly increased by exposure to the restraint stress in the hippocampus of female 5XFAD mice $[F(1,12)=10.96, p=0.0062]$ (Figure $2 \mathrm{E}, \mathrm{F}$ ) but not in that of male 5XFAD mice (Figure $2 \mathrm{~B}, \mathrm{C}$ ). In the cerebral cortex, non-stressed male and female 5XFAD mice exhibited faint amyloid deposition (mainly, 


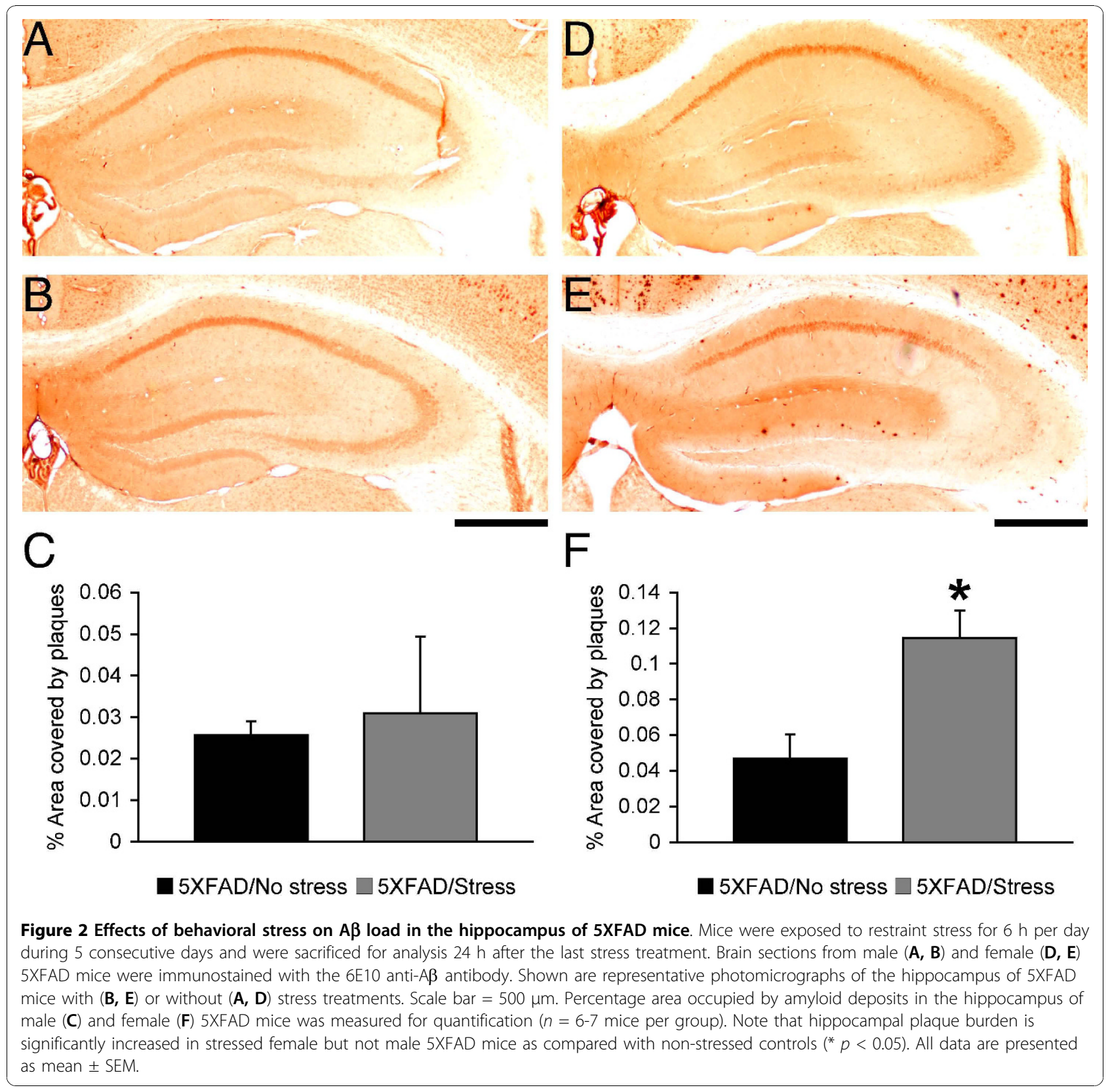

in layer 5); however, stress treatments did not affect cortical $\mathrm{A} \beta$ burden in male or female 5XFAD mice (data not shown). Taken together, 5-day restraint stress elevated A $\beta 42$ concentrations ( $\sim 2.7$-fold $)$, leading to the higher plaque load $(\sim 2.4$-fold $)$ specifically in the hippocampus of female 5XFAD mice.

\section{Behavioral stress elevates BACE1 and APP levels in 5XFAD} mice in a sex- and brain region-dependent manner

To address the mechanisms underlying sex- and brain region-specific acceleration of $\mathrm{A} \beta$ accumulation following exposure to adverse stress in 5XFAD mice, we first compared stress-induced changes in hippocampal $\beta$-amyloidogenic APP processing between male and female 5XFAD mice (Figure 3). Immunoblot analysis of hippocampal homogenates from male (Figure 3A) and female (Figure $3 \mathrm{~B}$ ) mice demonstrated that 5-day exposure to restraint stress did not change BACE1 levels in male 5XFAD mice (Figure 3C), whereas it increased BACE1 expression in female 5XFAD mice (Figure 3D). A one-way ANOVA and post-hoc Fisher's PLSD test revealed that BACE1 levels in the hippocampus of stressed female 5XFAD mice were significantly higher than those of non-stressed wild-type and 5XFAD mice 


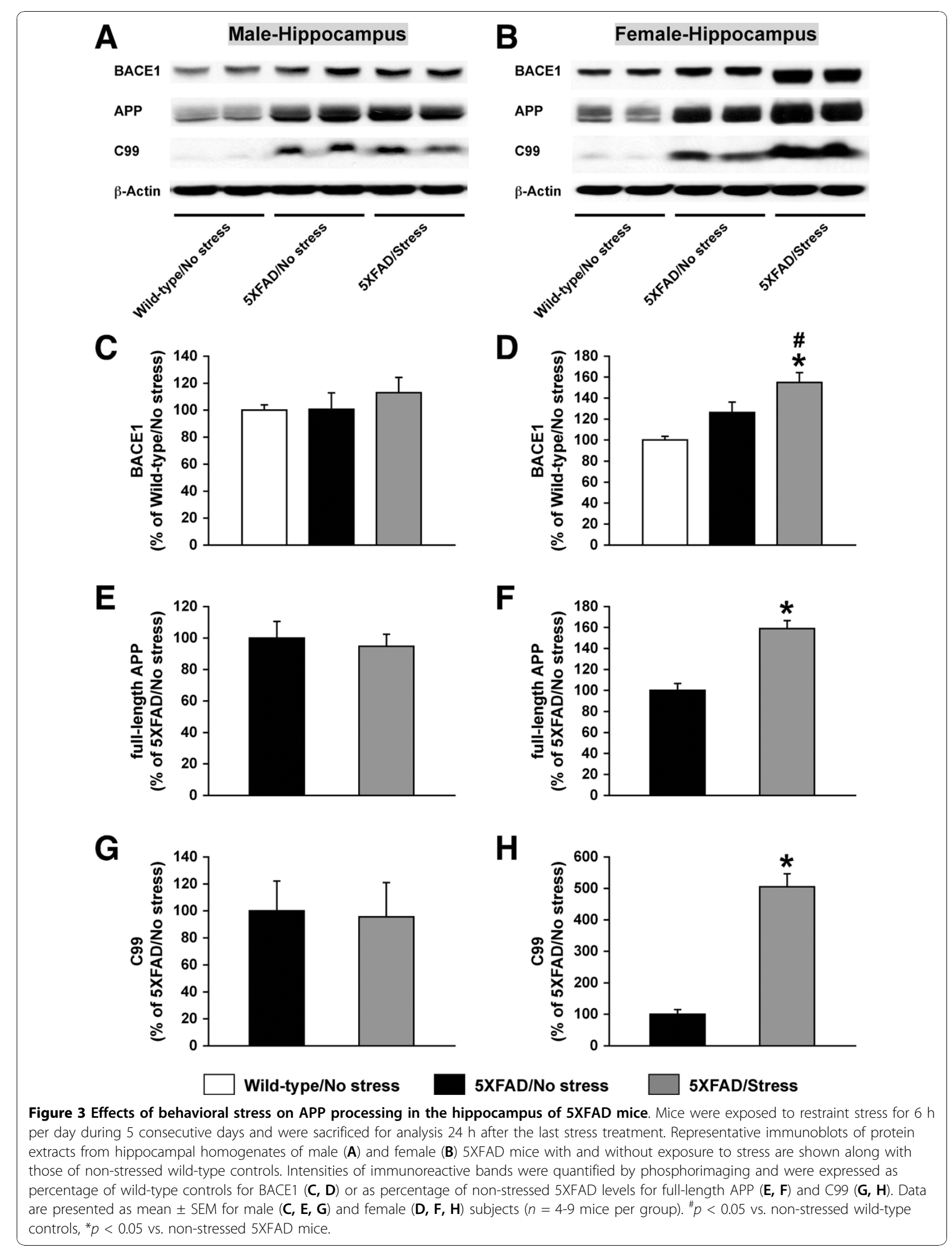


$[F(2,18)=10.40, p=0.001]$. Transgene-derived overexpression of human APP in 5XFAD mice was several folds relative to endogenous levels of APP detected in wild-type controls (Figure 3A, B). Similar to changes in BACE1 levels, the stress treatment significantly elevated levels of hippocampal full-length APP in female 5XFAD mice $[F(1,14)=32.47, p<0.0001]$ (Figure 3F) but not in male 5XFAD mice (Figure 3E). In consequence, levels of the $\beta$-secretase-cleaved $C$-terminal fragment (C99) were not altered in the hippocampus of stressed male 5XFAD mice (Figure 3G), while C99 levels were dramatically elevated $(\sim 5$-fold $)$ in that of stressed female 5XFAD mice compared with non-stressed 5XFAD controls $[F$ $(1,14)=67.21, p<0.0001$ ] (Figure 3H). We also tested how the same 5-day restraint stress would affect APP processing in the cerebral cortex of male and female 5XFAD mice. In contrast to changes observed in the hippocampus, the adverse behavioral stress did not significantly affect cortical BACE1 or full-length APP levels in male or female 5XFAD mice (data not shown). Collectively, 5-day exposure to restraint stress induced a marked increase of C99 levels, which was accompanied by significant elevations in both BACE1 and APP expression, specifically in the hippocampus of female 5XFAD mice consistent with the significantly increased A $\beta 42$ concentrations and plaque burden (Figures 1 and 2).

\section{Transcriptional and translational mechanisms underlie sex- and brain region-dependent BACE1 elevation in 5XFAD mice following behavioral stress}

Recent evidence suggests that phosphorylation of the translation initiation factor eIF2 $\alpha$ (phospho-eIF2 $\alpha$ ) plays an important role in mediating the post-transcriptional upregulation of BACE1 in sporadic AD and 5XFAD mouse brains at advanced stages of disease that develop massive amyloid pathology [24-26]. We first examined whether the phospho-eIF2 $\alpha$ pathway was involved in the behavioral stress-induced BACE1 elevation in 5XFAD model mice (Figure 4). The baseline levels of phospho-eIF2 $\alpha$ in non-stressed 5XFAD mice at the prepathological stage were not significantly different from those of wild-type control mice irrespective of sex or brain regions. In parallel with changes in BACE1 expression, 5-day restraint stress significantly increased phospho-eIF $2 \alpha$ levels without affecting total eIF2 $\alpha$ levels in the hippocampus of female 5 XFAD mice $[F(2,22)=$ $8.70, p=0.0016]$. In contrast, the other three groups of 5XFAD brain samples showed no significant changes in phospho-eIF2 $\alpha$ levels between stressed and non-stressed animals. Moreover, qPCR analysis revealed that BACE1 mRNA levels were also significantly higher in the hippocampus of female 5XFAD mice exposed to behavioral stress as compared with that of non-stressed controls
$[F(1,6)=20.00, p=0.0042]$ (Figure 5). Taken collectively, the results clearly indicate that both transcriptional and translational mechanisms through activation of the eIF $2 \alpha$ phosphorylation pathway underlie the female hippocampus-specific elevation of BACE1 expression in response to behavioral stressors in the 5XFAD model.

\section{Discussion}

Very few AD cases can be attributable to genetic causes, while the etiology of sporadic AD that constitutes the majority of AD cases remains unclear [3,4]. Nevertheless, most transgenic models of AD are created based on a simple genetic association between the rare inherited form of FAD and excessive $A \beta$ production and do not encompass acquired characteristics [27-30]. Many nongenetic factors including age, lifestyle (e.g., daily stress and diets), medical history and education have been reported to contribute to increasing the risk for $\mathrm{AD}$ [31,32]. Epidemiological investigations also show gender differences in the incidence and prevalence of $\mathrm{AD}$ with females being at higher risk [12-14], although a biological foundation for gender differences remains to be determined. In this study, we applied a relatively brief behavioral stress to male and female 5XFAD transgenic model mice at the pre-pathological stage of disease that shows little or only faint amyloid deposition, and tested the hypothesis that sex and stress interactions may represent a key mechanism underlying sporadic $A D$ and rendering women more prone to develop AD.

Our results clearly demonstrated that 5 -day exposure to restraint stress increased levels of $A \beta 42$ peptides, a pathogenic $A \beta$ species that is more hydrophobic and has the propensity to assemble into neurotoxic oligomers and aggregates [33-35], in the hippocampus of female 5XFAD mice but not in male 5XFAD mice. Meanwhile, the same stress treatment did not significantly affect $A \beta 42$ levels in the cerebral cortex of male or female 5XFAD mice. Accordingly, amyloid plaque formation was also accelerated specifically in the female 5XFAD hippocampus following restraint stress. Interestingly, previous studies applied much longer stress treatments (e.g., several months of immobilization and/or isolation) to APP transgenic mice and showed that such prolonged stress exposures resulted in elevated $A \beta$ concentrations and pathology in both the hippocampus and cortex without distinction based on sex [8-11]. Therefore, it should be noted that only 5-day exposure to restraint stress was sufficient to significantly elevate levels of $A \beta 42$ and plaque load in 5XFAD mice in this study. Of particular importance, such a brief stress treatment revealed that the hippocampus of females is vulnerable and prone to develop amyloid deposits in response to adverse behavioral stressors. These findings support the idea that the 


\section{Female-Hippocampus}

p-elF $2 \alpha$

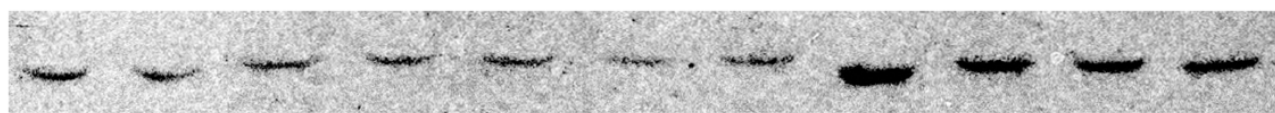

Total elF $2 \alpha$
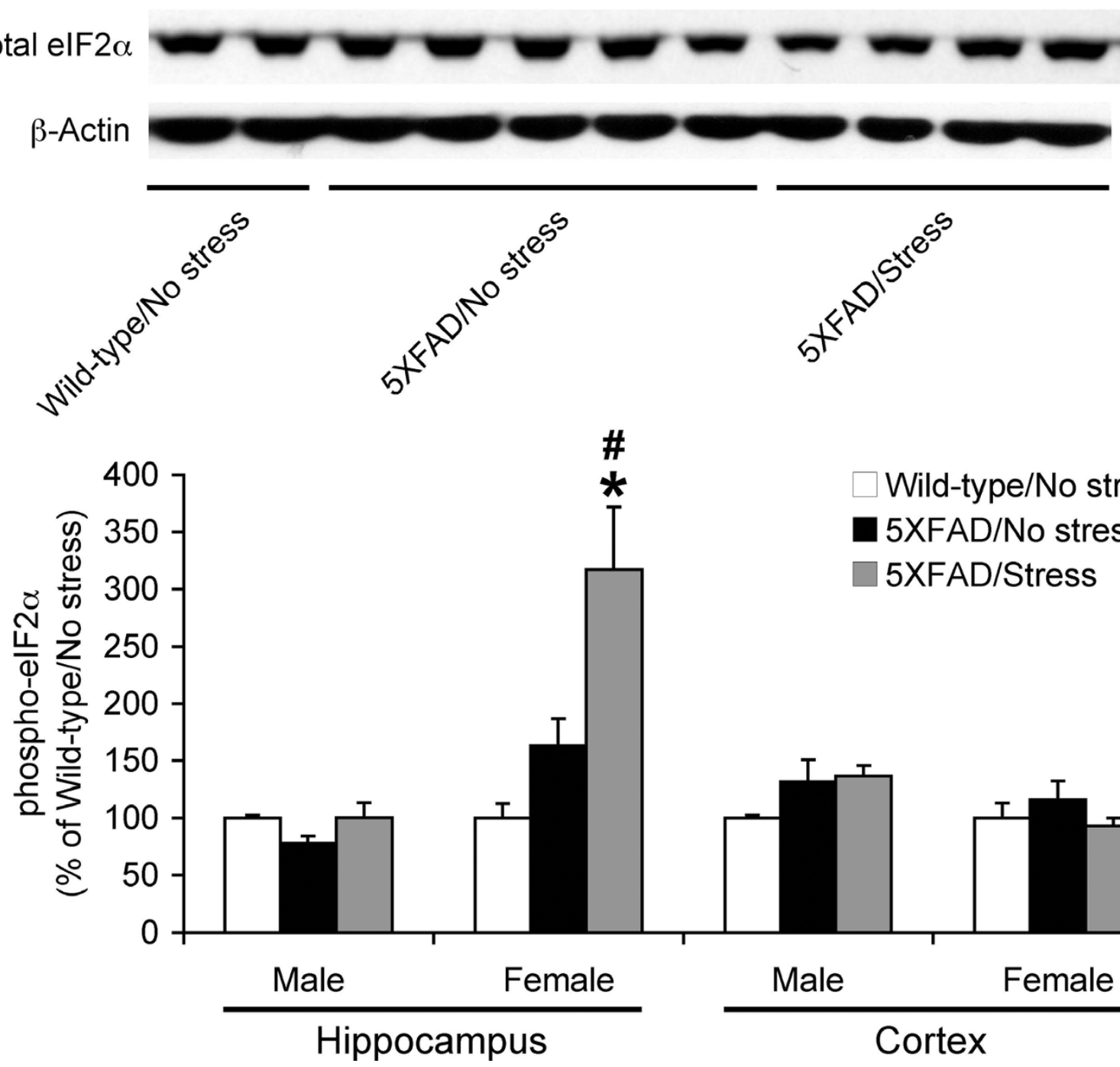

Wild-type/No stress

5XFAD/No stress

5XFAD/Stress

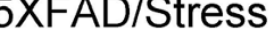

Figure 4 Effects of behavioral stress on phospho-elF2 $\alpha$ levels in the hippocampus and cerebral cortex of 5XFAD mice. Male and female mice were exposed to restraint stress for $6 \mathrm{~h}$ per day during 5 consecutive days and were sacrificed for analysis $24 \mathrm{~h}$ after the last stress treatment. Representative immunoblots of phosphorylated elF $2 \alpha$ (p-elF $2 \alpha$ ) and total elF2 $\alpha$ for hippocampal homogenates of female 5XFAD mice with and without exposure to stress are shown along with those of non-stressed wild-type controls. Intensities of $p$-elF2 $\alpha$-immunoreactive bands were quantified by phosphorimaging and were expressed as percentage of wild-type controls ( $n=3-9$ mice per group). Note that p-elF2 $\alpha$ levels, but not total elF2 $\alpha$ levels, are increased specifically in the hippocampus of stressed female 5XFAD mice as compared with non-stressed wild-type controls $\left({ }^{\#} p<0.05\right)$ and non-stressed 5XFAD mice $\left({ }^{*} p<0.05\right)$. All data are presented as mean \pm SEM.

higher prevalence of sporadic AD in women may be, at least in part, attributable to the vulnerability of female brain, especially the hippocampus, to stress mechanisms that favor $\beta$-amyloidogenic processing of APP. This is also consistent with the observation that hippocampal $\mathrm{A} \beta$ deposition is one of the earliest features of $\mathrm{AD}$ [36].
What mechanisms underlie the sex- and brain regionspecific acceleration of $A \beta$ accumulation following brief stress exposure? Previous studies demonstrate a sex difference in stress effects and estrogens are known to potentiate the glucocorticoid secretion under stress conditions $[37,38]$. This mechanism may represent the key 


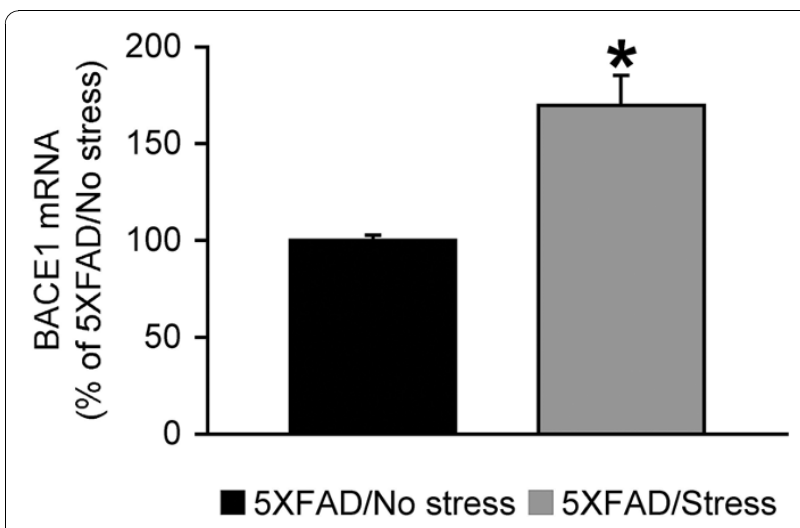

Figure 5 Effects of behavioral stress on BACE1 mRNA levels in the hippocampus of female 5XFAD mice. Mice were exposed to restraint stress for $6 \mathrm{~h}$ per day during 5 consecutive days and were sacrificed for real-time $\mathrm{QPCR}$ analysis $24 \mathrm{~h}$ after the last stress treatment. BACE1 mRNA levels were significantly elevated in the hippocampus of stressed female 5XFAD mice as compared with that of non-stressed 5XFAD controls $\left({ }^{*} p<0.05\right)(n=4$ mice per group). All data are presented as mean \pm SEM.

component of the stress response that promotes $\beta$-amyloidosis more profoundly in female 5XFAD brains. Alternatively, recent studies have started to reveal the involvement of gender-specific molecular signaling processes or sex chromosome gene expression in addition to estrogen effects in causing sex differences in neuronal function $[39,40]$. Further study is needed to address the precise mechanisms including interactions between sex hormones and different stress mediators linking with changes in neuronal amyloidogenic processing of APP associated with $\mathrm{AD}$.

Importantly, we found that BACE1 expression was elevated specifically in the hippocampus of stressed female 5XFAD mice in accordance with increased levels of $A \beta 42$ and plaque burden. It has been reported that protein and/or activity levels of BACE1 become elevated in brains of sporadic AD patients [19-21,41] and 5XFAD mice $[26,42-44]$ as disease progresses into the severer pathological stage with established amyloid plaques. Recent studies including ours demonstrate that phosphorylation of the translation initiation factor eIF2 $\alpha$ plays a critical role in mediating the post-transcriptional upregulation of BACE1 associated with AD $[25,26]$. Increases in phospho-eIF $2 \alpha$ levels occur in brains of sporadic $\mathrm{AD}$ and advanced pathological stages of APP transgenic mice including the 5XFAD model [24-26,45,46] and are shown to correlate with BACE1 elevation $[25,26]$. In the present study, baseline phospho-eIF2 $\alpha$ levels of non-stressed 5XFAD mice at the pre-pathological stage were not significantly different from those of wild-type control mice, while they were increased by 5 -day restraint stress exposure specifically in the hippocampus of female 5XFAD mice in line with BACE1 elevation. Therefore, these results suggest that the phospho-eIF2 $\alpha$-dependent translational upregulation of BACE1 in response to behavioral stressors may represent an important molecular mechanism by which environmental factors initiate $\beta$-amyloidogenesis before significant $A \beta$ deposition occurs during the early phase of sporadic AD. This hypothesis is strongly supported by our recent observation that the increase in phosphoeIF2 $\alpha$ induced by Sal 003, a specific inhibitor of its phosphatase, elevates BACE1 levels in younger 5XFAD mice, which have not yet showed BACE1 upregulation at basal levels concomitant with only marginal increases in eIF2 $\alpha$ phosphorylation [26].

In addition to the translational mechanism, transcriptional control of BACE1 may also be implicated in AD pathogenesis $[47,48]$. In this study, we showed the increase of BACE1 mRNA level in the hippocampus of stressed female 5XFAD mice compared with that of non-stressed controls, suggesting a possibility that transcriptional mechanisms may also contribute to the BACE1 elevation associated with adverse behavioral stress. Our results are consistent with the findings that the promoter region of BACE1 gene contains glucocorticoid responsive elements [49] and that glucocorticoid administration facilitates $A \beta$ production possibly via increases in transcription of the BACE1 gene through this binding site [50]. Some studies with postmortem human brains report elevations in BACE1 mRNA levels associated with sporadic AD [21,51], while others show no changes in mRNA despite the increased levels of BACE1 activity and protein [22,52-54]. Therefore, the mechanisms underlying BACE1 elevation in the sporadic AD brain remain controversial, which may be accounted for by differences in complex environmental factors mainly responsible for the disease progression. Our mouse model study suggests that both transcriptional and translational mechanisms may underlie BACE1 elevations associated with adverse stress during the development of AD.

Intriguingly, we also found that stress-responsive increases in APP expression levels occurred only in the hippocampus of female 5XFAD mice. Therefore, it seems likely that elevations in both BACE1 and its substrate APP work cooperatively to enable dramatic increases in the intermittent $\beta$-cleaved $C$-terminal fragment $\mathrm{C} 99$ and the acceleration of $\mathrm{A} \beta 42$ production and plaque formation in the hippocampus of female 5XFAD mice following 5-day exposure to behavioral stress. Given that $A \beta$ and $C 99$ peptides are amyloidogenic and can induce synaptic failure, neurodegeneration and memory loss [34,55-59], behavioral stress-dependent elevations in both $\beta$-cleavage products through BACE1 
and APP upregulation have important implications for the pathogenesis of sporadic $\mathrm{AD}$ and the progression of neuronal dysfunction. Our findings are in agreement with recent reports showing that exposure to stress-level glucocorticoids (daily injections of dexamethasone for 7-21 days) elevates both BACE1 and APP levels leading to accelerated $C 99$ production and $A \beta$ accumulation $[50,60,61]$. However, these pharmacologically induced stress responses seem more robust than the behavioral stress regimen applied in this study as the changes are observed in brains of male subjects including 3xTg-AD transgenic model mice and middle-aged wild-type mice or rats. In any case, our present study combined with others indicates that elevated levels of glucocorticoids found in sporadic AD brains [62-64] may not only be a consequence of the pathology but also play a causal role in triggering $\beta$-amyloidogenesis through BACE1 and APP elevations during earlier stages of disease progression.

\section{Conclusions}

Our mouse model study clearly demonstrates that the responsiveness of brains (especially, hippocampal neurons) to stress conditions, which shift APP processing toward $\beta$-amyloidogenesis by upregulating BACE1 and its substrate APP, represents a crucial contributing factor in the development of sporadic AD and may account for a mechanism underlying the increased prevalence of women to develop AD. Moreover, our data also suggest that transcriptional and translational mechanisms may underlie BACE1 elevation in response to adverse stressors, supporting the idea that therapeutic interventions aimed at suppressing stress-related signaling pathways (e.g., reduction of glucocorticoids or eIF $2 \alpha$ phosphorylation) may be beneficial for slowing down $\mathrm{AD}$ progression.

\section{Methods}

\section{Animals}

We used 5XFAD transgenic mice that co-overexpress FAD mutant forms of human APP (the Swedish mutation: K670N, M671L; the Florida mutation: I716V; the London mutation: V717I) and presenilin-1 (PS1: M146L, L286V) transgenes under transcriptional control of the neuron-specific mouse Thy-1 promoter (Tg6799 line) $[23,65]$. 5XFAD lines (B6/SJL genetic background) were maintained by crossing hemizygous transgenic mice with B6/SJL F1 breeders (Taconic, Hudson, NY). 5XFAD transgenic mice used were hemizygotes with respect to the transgene and non-transgenic wild-type littermate mice served as controls. Genotyping was performed by PCR analysis of tail DNA. All experiments were done blind with respect to the genotype of the mice, and were conducted with the approval of the Nathan Kline Institute Animal Care and Use Committee.

\section{Behavioral stress}

Stressed 5XFAD mice were individually placed in a wellventilated plastic tube (Diameter: $3.8 \mathrm{~cm})(541-\mathrm{RR}$, PlasLabs, Lansing, MI) and restrained for $6 \mathrm{~h}$ per day during 5 consecutive days. After each stress session, the mice were returned to their cage where they were housed in isolation with free access to food and water. Twentyfour hours after the last exposure to restraint stress, brain samples were collected. The timing of stress treatments was arranged so that 5 XFAD mice were precisely at 3 months of age when sacrificed. Non-stressed control mice were kept group-housed in their home cage and were sacrificed for analysis at 3 months of age.

\section{A $\beta 42$ ELISA}

Sandwich A $\beta$ ELISA was performed as described previously $[66,67]$. Briefly, each hemibrain sample was extracted in $8 \mathrm{X}$ cold $5 \mathrm{M}$ guanidine $\mathrm{HCl}$ plus $50 \mathrm{mM}$ Tris $\mathrm{HCl}(\mathrm{pH} 8.0)$ buffer, and centrifuged at 20,000 g for $1 \mathrm{~h}$ at $4^{\circ} \mathrm{C}$ to remove insoluble material. Final guanidine $\mathrm{HCl}$ concentrations were below $0.1 \mathrm{M}$. Protein concentrations were determined by a BCA protein assay kit (Pierce, Rockford, IL). To quantitate total levels of cerebral $A \beta 42$, supernatant fractions were analyzed by a well-established human A 342 ELISA kits (KHB3441, Invitrogen, Carlsbad, CA) according to the protocol of the manufacturer. Optical densities at $450 \mathrm{~nm}$ of each well were read on a VersaMax tunable microplate reader (Molecular Devices, Sunnyvale, CA), and sample A $\beta 42$ concentrations were determined by comparison with the standard curves. A $\beta 42$ concentration values were normalized to total brain protein concentrations and expressed in nanograms per milligram of total protein.

\section{$A \beta$ immunohistochemistry}

Mice were transcardially perfused with $4 \%$ paraformaldehyde in phosphate buffered saline (PBS) under deep isoflurane anesthesia. The brain was removed and sectioned coronally at $40 \mu \mathrm{m}$ on a vibratome (VT1200, Leica Microsystems, Wetzlar, Germany), and successive sections were stored in PBS containing $0.01 \%$ sodium azide at $4^{\circ} \mathrm{C}$. Four sections per mouse were stained by the avidin-biotin peroxidase complex method for immunohistochemical analysis of amyloid deposition in the hippocampus and cerebral cortex [66,67]. Each section was separated by $\sim 120 \mu \mathrm{m}$ and taken at levels of $-1.5 /$ $1.9 \mathrm{~mm}$ to bregma according to the mouse brain atlas of Franklin and Paxinos [68]. The sections were incubated overnight at $4^{\circ} \mathrm{C}$ with monoclonal anti-A $\beta 1-16$ antibody (1:200; 6E10, Signet, Dedham, MA). The ABC kit (PK2200, Vector Laboratories, Burlingame, CA) was utilized with 3,3'-diaminobenzidine tetrahydrochloride as a chromogen to visualize the reaction product. The sections were then mounted on charged slides, dehydrated in a 
series of alcohol, cleared in xylene, and covered with a coverslip. Light microscopy was conducted on an Axioskop 2 microscope equipped with an AxioCaM HRc digital camera (Zeiss, Munich, Germany) for capturing images. Semi-quantitative analysis was performed using AxioVision imaging software with the AutoMeasure module (Zeiss). Identified objects after thresholding were individually inspected to confirm the object as a plaque or not in a blinded manner. Percentage area occupied by $\mathrm{A} \beta$ deposits in the hippocampus and cortex was assessed bilaterally, and the average of the individual measurements from each mouse was calculated to compare plaque load between the stressed and nonstressed 5XFAD mice.

\section{Immunoblot analysis}

Hippocampal and cortical samples were taken from the mice under deep isoflurane anesthesia and were snapfrozen for Western blot analysis [66,67]. Each sample was homogenized in 5 volumes of modified RIPA buffer containing $150 \mathrm{mM} \mathrm{NaCl}, 50 \mathrm{mM}$ Tris $\mathrm{HCl}(\mathrm{pH} 8.0), 1$ mM EDTA, 1\% IGEPAL, 0.5\% sodium deoxycholate, $0.1 \%$ SDS and protease/phosphatase inhibitor cocktails (Calbiochem, La Jolla, CA), and centrifuged at 10,000 g for $10 \mathrm{~min}$ to remove any insoluble material. Protein concentrations were determined by a BCA kit (Pierce), and $20-50 \mu \mathrm{g}$ of protein was run on $4-12 \%$ NuPAGE gels (Invitrogen) and transferred to nitrocellulose membrane. After blocking, membranes were probed with anti-BACE1 (1:1,000, MAB5308, Millipore, Billerica, $\mathrm{MA}$ ), an antibody that recognizes $C$-terminal epitope in APP (1:1,000, C1/6.1, kindly provided by Dr. Paul Mathews, Nathan Kline Institute) to detect full-length APP/ C-terminal fragments, anti-phospho-eIF2 $\alpha$ (Ser51) (1:1,000, \#3398, Cell Signaling Technology, Danvers, MA), anti-eIF2 $\alpha$ (1:1,000, \#9722, Cell Signaling Technology) or anti- $\beta$-actin (1:15,000, AC-15, Sigma, St. Louis, $\mathrm{MO})$. They were then incubated with horseradish peroxidase-conjugated secondary IgG. Immunoblot signals were visualized by an ECL chemiluminescence substrate reagent kit (Pierce) and were quantified by densitometric scanning and image analysis using Quantity One software (Bio-Rad Laboratories, Hercules, CA).

\section{Real-time qPCR}

qPCR was performed in triplicate on frozen hippocampal samples as described previously [69,70]. TaqMan qPCR primers were utilized for mouse BACE1 mRNA (Mm00478671_m1, Applied Biosystems, Foster City, $\mathrm{CA}$ ) and the housekeeping gene glyceraldehyde-3-phosphate dehydrogenase (GAPDH, Mm99999915_g1, Applied Biosystems). Samples were assayed on a realtime qPCR cycler (7900HT, Applied Biosystems) in 96-well optical plates covered with optical adhesive film.
Standard curves and cycle threshold were generated using standards obtained from total mouse brain RNA. The delta delta cycle threshold (ddCT) method was employed to determine relative gene level differences between stressed and non-stressed 5XFAD mice with GAPDH qPCR products used as a control, and expression levels were presented as percentage of non-stress controls. Negative controls consisted of the reaction mixture without input RNA.

\section{Statistical analysis}

The significance of differences between the groups was determined by a one-way ANOVA and post-hoc Fisher's PLSD tests were performed when appropriate. Data were presented as mean \pm SEM and the level of significance was set for $p$ value less than 0.05 .

\section{Acknowledgements}

This work was supported by National Institutes of Health grant R01 MH067251 (M.O.) and Alzheimer's Association grant IIRG-08-91231 (M.O.).

\section{Author details}

${ }^{1}$ Center for Dementia Research, Nathan Kline Institute, Orangeburg, New York 10962, USA. ²Department of Psychiatry, New York University Langone Medical Center, New York, New York 10016, USA. ${ }^{3}$ Department of Physiology and Neuroscience, New York University Langone Medical Center, New York, New York 10016, USA

\section{Authors' contributions}

LD performed a majority of the experiments, analyzed the data and wrote the manuscript. MJA and SDG performed the GPCR experiment and

analyzed the data. MO designed the experiments and wrote the manuscript. All authors read and approved the final manuscript.

\section{Competing interests}

The authors declare that they have no competing interests.

Received: 28 July 2010 Accepted: 8 November 2010

Published: 8 November 2010

\section{References}

1. Hardy J: Amyloid, the presenilins and Alzheimer's disease. Trends Neurosci 1997, 20:154-159.

2. Selkoe DJ: Alzheimer's disease: genes, proteins, and therapy. Physiol Rev 2001, 81:741-766.

3. Blennow K, de Leon MJ, Zetterberg H: Alzheimer's disease. Lancet 2006, 368:387-403.

4. Wu J, Basha MR, Zawia NH: The environment, epigenetics and amyloidogenesis. J Mol Neurosci 2008, 34:1-7.

5. Rothman SM, Mattson MP: Adverse stress, hippocampal networks, and Alzheimer's disease. Neuromolecular Med 2010, 12:56-70.

6. Wilson RS, Barnes LL, Bennett DA, Li Y, Bienias JL, Mendes de Leon CF, Evans DA: Proneness to psychological distress and risk of Alzheimer disease in a biracial community. Neurology 2005, 64:380-382.

7. Wilson RS, Arnold SE, Schneider JA, Kelly JF, Tang Y, Bennett DA: Chronic psychological distress and risk of Alzheimer's disease in old age. Neuroepidemiology 2006, 27:143-153.

8. Jeong YH, Park CH, Yoo J, Shin KY, Ahn SM, Kim HS, Lee SH, Emson PC, Suh $\mathrm{YH}$ : Chronic stress accelerates learning and memory impairments and increases amyloid deposition in APPV717I-CT100 transgenic mice, an Alzheimer's disease model. FASEB J 2006, 20:729-731.

9. Dong H, Goico B, Martin M, Csernansky CA, Bertchume A, Csernansky JG: Modulation of hippocampal cell proliferation, memory, and amyloid plaque deposition in APPsw (Tg2576) mutant mice by isolation stress. Neuroscience 2004, 127:601-609. 
10. Dong H, Yuede CM, Yoo HS, Martin MV, Deal C, Mace AG, Csernansky JG: Corticosterone and related receptor expression are associated with increased $\beta$-amyloid plaques in isolated Tg2576 mice. Neuroscience 2008, 155:154-163.

11. Lee KW, Kim JB, Seo JS, Kim TK, Im JY, Baek IS, Kim KS, Lee JK, Han PL: Behavioral stress accelerates plaque pathogenesis in the brain of Tg2576 mice via generation of metabolic oxidative stress. J Neurochem 2009, 108:165-175.

12. Baum LW: Sex, hormones, and Alzheimer's disease. J Gerontol A Biol Sci Med Sci 2005, 60:736-743.

13. Andersen K, Launer $L$, Dewey ME, Letenneur L, Ott A, Copeland JR, Dartigues JF, Kragh-Sorensen P, Baldereschi M, Brayne C, Lobo A, MartinezLage JM, Stijnen T, Hofman A: Gender differences in the incidence of AD and vascular dementia: The EURODEM Studies. EURODEM Incidence Research Group. Neurology 1999, 53:1992-1997.

14. Hy $L X$, Keller DM: Prevalence of $A D$ among whites: a summary by levels of severity. Neurology 2000, 55:198-204.

15. Kim JJ, Diamond DM: The stressed hippocampus, synaptic plasticity and lost memories. Nat Rev Neurosci 2002, 3:453-462.

16. Shors TJ, Chua C, Falduto J: Sex differences and opposite effects of stress on dendritic spine density in the male versus female hippocampus. $J$ Neurosci 2001, 21:6292-6297.

17. Bangasser DA, Shors TJ: The hippocampus is necessary for enhancements and impairments of learning following stress. Nat Neurosci 2007, 10:1401-1403.

18. Waddell J, Bangasser DA, Shors TJ: The basolateral nucleus of the amygdala is necessary to induce the opposing effects of stressful experience on learning in males and females. J Neurosci 2008 28:5290-5294.

19. Fukumoto $H$, Cheung BS, Hyman BT, Irizarry MC: $\beta$-Secretase protein and activity are increased in the neocortex in Alzheimer disease. Arch Neurol 2002, 59:1381-1389.

20. Yang LB, Lindholm K, Yan R, Citron M, Xia W, Yang XL, Beach T, Sue L, Wong $P$, Price $D$, Li R, Shen Y: Elevated $\beta$-secretase expression and enzymatic activity detected in sporadic Alzheimer disease. Nat Med 2003, 9:3-4.

21. Li R, Lindholm $K$, Yang LB, Yue $X$, Citron $M$, Yan $R$, Beach $T$, Sue $L$, Sabbagh $M$, Cai $H$, Wong $P$, Price $D$, Shen $Y$ : Amyloid $\beta$ peptide load is correlated with increased $\beta$-secretase activity in sporadic Alzheimer's disease patients. Proc Natl Acad Sci USA 2004, 101:3632-3637.

22. Matsui $T$, Ingelsson M, Fukumoto $H$, Ramasamy K, Kowa $H$, Frosch MP, Irizarry MC, Hyman BT: Expression of APP pathway mRNAs and proteins in Alzheimer's disease. Brain Res 2007, 1161:116-123.

23. Oakley H, Cole SL, Logan S, Maus E, Shao P, Craft J, Guillozet-Bongaarts A, Ohno M, Disterhoft J, Van Eldik L, Berry R, Vassar R: Intraneuronal $\beta$ amyloid aggregates, neurodegeneration, and neuron loss in transgenic mice with five familial Alzheimer's disease mutations: potential factors in amyloid plaque formation. J Neurosci 2006, 26:10129-10140.

24. Chang RC, Wong AK, Ng HK, Hugon J: Phosphorylation of eukaryotic initiation factor-2a (elF2a) is associated with neuronal degeneration in Alzheimer's disease. Neuroreport 2002, 13:2429-2432.

25. O'Connor T, Sadleir KR, Maus E, Velliquette RA, Zhao J, Cole SL, Eimer WA, Hitt B, Bembinster LA, Lammich S, Lichtenthaler SF, Hebert SS, De Strooper B, Haass C, Bennett DA, Vassar R: Phosphorylation of the translation initiation factor elF2 $\alpha$ increases BACE1 levels and promotes amyloidogenesis. Neuron 2008, 60:988-1009.

26. Devi L, Ohno M: Phospho-elF2a level is important for determining abilities of BACE1 reduction to rescue cholinergic neurodegeneration and memory defects in 5XFAD mice. PLoS One 2010, 5:e12974.

27. McGowan E, Eriksen J, Hutton M: A decade of modeling Alzheimer's disease in transgenic mice. Trends Genet 2006, 22:281-289.

28. Gotz J, Streffer JR, David D, Schild A, Hoerndli F, Pennanen L, Kurosinski P Chen F: Transgenic animal models of Alzheimer's disease and related disorders: histopathology, behavior and therapy. Mol Psychiatry 2004, 9:664-683.

29. Gotz J, Ittner LM: Animal models of Alzheimer's disease and frontotemporal dementia. Nat Rev Neurosci 2008, 9:532-544.

30. Morrissette DA, Parachikova A, Green KN, LaFerla FM: Relevance of transgenic mouse models to human Alzheimer disease. J Biol Chem 2009, 284:6033-6037.
31. McDowell I: Alzheimer's disease: insights from epidemiology. Aging (Milano) 2001, 13:143-162.

32. Qiu C, Kivipelto M, von Strauss E: Epidemiology of Alzheimer's disease: occurrence, determinants, and strategies toward intervention. Dialogues Clin Neurosci 2009, 11:111-128.

33. Findeis MA: The role of amyloid $\beta$ peptide 42 in Alzheimer's disease. Pharmacol Ther 2007, 116:266-286.

34. McGowan E, Pickford F, Kim J, Onstead L, Eriksen J, Yu C, Skipper L, Murphy MP, Beard J, Das P, Jansen K, Delucia M, Lin WL, Dolios G, Wang R, Eckman CB, Dickson DW, Hutton M, Hardy J, Golde T: A 442 is essential for parenchymal and vascular amyloid deposition in mice. Neuron 2005, 47:191-199.

35. Haass $C$, Selkoe DJ: Soluble protein oligomers in neurodegeneration: lessons from the Alzheimer's amyloid $\beta$-peptide. Nat Rev Mol Cell Biol 2007, 8:101-112.

36. de Leon MJ, DeSanti S, Zinkowski R, Mehta PD, Pratico D, Segal S, Clark C, Kerkman D, DeBernardis J, Li J, Lair L, Reisberg B, Tsui W, Rusinek H: MRI and CSF studies in the early diagnosis of Alzheimer's disease. J Intern Med 2004, 256:205-223.

37. Sotiropoulos I, Cerqueira JJ, Catania C, Takashima A, Sousa N, Almeida OF: Stress and glucocorticoid footprints in the brain-the path from depression to Alzheimer's disease. Neurosci Biobehav Rev 2008 32:1161-1173.

38. Weiser MJ, Handa RJ: Estrogen impairs glucocorticoid dependent negative feedback on the hypothalamic-pituitary-adrenal axis via estrogen receptor alpha within the hypothalamus. Neuroscience 2009, 159:883-895.

39. Mizuno K, Giese KP: Towards a molecular understanding of sex differences in memory formation. Trends Neurosci 2010, 33:285-291.

40. Andreano JM, Cahill L: Sex influences on the neurobiology of learning and memory. Learn Mem 2009, 16:248-266.

41. Ahmed RR, Holler CJ, Webb RL, Li F, Beckett TL, Murphy MP: BACE1 and BACE2 enzymatic activities in Alzheimer's disease. J Neurochem 2010, 112:1045-1053.

42. Ohno M, Cole SL, Yasvoina M, Zhao J, Citron M, Berry R, Disterhoft JF, Vassar R: BACE1 gene deletion prevents neuron loss and memory deficits in 5XFAD APP/PS1 transgenic mice. Neurobiol Dis 2007, 26:134-145.

43. Zhao J, Fu Y, Yasvoina M, Shao P, Hitt B, O'Connor T, Logan S, Maus E, Citron $M$, Berry $R$, Binder $L$, Vassar R: $\beta$-Site amyloid precursor protein cleaving enzyme 1 levels become elevated in neurons around amyloid plaques: implications for Alzheimer's disease pathogenesis. J Neurosci 2007, 27:3639-3649.

44. Zhang X-M, Cai Y, Xiong K, Cai H, Luo X-G, Feng J-C, Clough RW, Struble RG, Patrylo PR, Yan $X-X$ : $\beta$-Secretase-1 elevation in transgenic mouse models of Alzheimer's disease is associated with synaptic/axonal pathology and amyloidogenesis: implications for neuritic plaque development. Eur J Neurosci 2009, 30:2271-2283.

45. Page G, Rioux Bilan A, Ingrand S, Lafay-Chebassier C, Pain S, Perault Pochat MC, Bouras C, Bayer T, Hugon J: Activated double-stranded RNAdependent protein kinase and neuronal death in models of Alzheimer's disease. Neuroscience 2006, 139:1343-1354.

46. Kim HS, Choi Y, Shin KY, Joo Y, Lee YK, Jung SY, Suh YH, Kim JH: Swedish amyloid precursor protein mutation increases phosphorylation of elF2a in vitro and in vivo. J Neurosci Res 2007, 85:1528-1537.

47. Rossner S, Sastre M, Bourne K, Lichtenthaler SF: Transcriptional and translational regulation of BACE1 expression - implications for Alzheimer's disease. Prog Neurobiol 2006, 79:95-111.

48. Wen Y, Yu WH, Maloney B, Bailey J, Ma J, Marie I, Maurin T, Wang L, Figueroa H, Herman M, Krishnamurthy P, Liu L, Planel E, Lau LF, Lahiri DK, Duff K: Transcriptional regulation of $\beta$-secretase by $\mathrm{p} 25 / \mathrm{cdk} 5$ leads to enhanced amyloidogenic processing. Neuron 2008, 57:680-690.

49. Sambamurti $K$, Kinsey R, Maloney B, Ge YW, Lahiri DK: Gene structure and organization of the human $\beta$-secretase (BACE) promoter. FASEB J 2004, 18:1034-1036

50. Green KN, Billings LM, Roozendaal B, McGaugh $\mathrm{L}$, LaFerla FM: Glucocorticoids increase amyloid- $\beta$ and tau pathology in a mouse model of Alzheimer's disease. J Neurosci 2006, 26:9047-9056. 
51. Coulson DT, Beyer N, Quinn JG, Brockbank S, Hellemans J, Brent G, Ravid R, Johnston JA: BACE1 mRNA Expression in Alzheimer's Disease Postmortem Brain Tissue. J Alzheimers Dis 2010.

52. Holsinger RM, McLean CA, Beyreuther K, Masters CL, Evin G: Increased expression of the amyloid precursor $\beta$-secretase in Alzheimer's disease. Ann Neurol 2002, 51:783-786.

53. Borghi R, Patriarca S, Traverso N, Piccini A, Storace D, Garuti A, Gabriella C, Patrizio O, Massimo T: The increased activity of BACE1 correlates with oxidative stress in Alzheimer's disease. Neurobiol Aging 2007, 28:1009-1014.

54. Preece P, Virley DJ, Costandi M, Coombes R, Moss SJ, Mudge AW, Jazin E, Cairns NJ: $\beta$-Secretase (BACE) and GSK-3 mRNA levels in Alzheimer's disease. Brain Res Mol Brain Res 2003, 116:155-158.

55. Geula C, Wu CK, Saroff D, Lorenzo A, Yuan M, Yankner BA: Aging renders the brain vulnerable to amyloid $\beta$-protein neurotoxicity. Nat Med 1998, 4:827-831

56. Shankar GM, Li S, Mehta TH, Garcia-Munoz A, Shepardson NE, Smith I, Brett FM, Farrell MA, Rowan MJ, Lemere CA, Regan CM, Walsh DM, Sabatini BL, Selkoe DJ: Amyloid- $\beta$ protein dimers isolated directly from Alzheimer's brains impair synaptic plasticity and memory. Nat Med 2008, 14:837-842.

57. Nalbantoglu J, Tirado-Santiago G, Lahsaini A, Poirier J, Goncalves O, Verge G, Momoli F, Welner SA, Massicotte G, Julien JP, Shapiro ML: Impaired learning and LTP in mice expressing the carboxy terminus of the Alzheimer amyloid precursor protein. Nature 1997, 387:500-505.

58. Choi SH, Park CH, Koo JW, Seo JH, Kim HS, Jeong SJ, Lee JH, Kim SS, Suh YH: Memory impairment and cholinergic dysfunction by centrally administered $A \beta$ and carboxyl-terminal fragment of Alzheimer's APP in mice. FASEB J 2001, 15:1816-1818.

59. Lee KW, Im JY, Song JS, Lee SH, Lee HJ, Ha HY, Koh JY, Gwag BJ, Yang SD, Paik SG, Han PL: Progressive neuronal loss and behavioral impairments of transgenic C57BL/6 inbred mice expressing the carboxy terminus of amyloid precursor protein. Neurobiol Dis 2006, 22:10-24.

60. Catania C, Sotiropoulos I, Silva R, Onofri C, Breen KC, Sousa N, Almeida OF: The amyloidogenic potential and behavioral correlates of stress. Mol Psychiatry 2009, 14:95-105.

61. Li WZ, Li WP, Yao YY, Zhang W, Yin YY, Wu GC, Gong HL: Glucocorticoids increase impairments in learning and memory due to elevated amyloid precursor protein expression and neuronal apoptosis in 12-month old mice. Eur J Pharmacol 2010, 628:108-115.

62. Swanwick GR, Kirby M, Bruce I, Buggy F, Coen RF, Coakley D, Lawlor BA: Hypothalamic-pituitary-adrenal axis dysfunction in Alzheimer's disease: lack of association between longitudinal and cross-sectional findings. Am J Psychiatry 1998, 155:286-289.

63. Masugi F, Ogihara T, Sakaguchi K, Otsuka A, Tsuchiya Y, Morimoto S, Kumahara Y, Saeki S, Nishide M: High plasma levels of cortisol in patients with senile dementia of the Alzheimer's type. Methods Find Exp Clin Pharmacol 1989, 11:707-710.

64. Csernansky JG, Dong H, Fagan AM, Wang L, Xiong C, Holtzman DM, Morris JC: Plasma cortisol and progression of dementia in subjects with Alzheimer-type dementia. Am J Psychiatry 2006, 163:2164-2169.

65. Ohno M, Chang L, Tseng W, Oakley H, Citron M, Klein WL, Vassar R, Disterhoft JF: Temporal memory deficits in Alzheimer's mouse models: rescue by genetic deletion of BACE1. Eur J Neurosci 2006, 23:251-260.

66. Kimura R, Devi L, Ohno M: Partial reduction of BACE1 improves synaptic plasticity, recent and remote memories in Alzheimer's disease transgenic mice. J Neurochem 2010, 113:248-261.

67. Devi L, Ohno M: Genetic reductions of $\beta$-site amyloid precursor proteincleaving enzyme 1 and amyloid- $\beta$ ameliorate impairment of conditioned taste aversion memory in 5XFAD Alzheimer's disease model mice. Eur $\lrcorner$ Neurosci 2010, 31:110-118.

68. Franklin KBJ, Paxinos G: The Mouse Brain in Stereotaxic Coordinates New York: Academic Press; 2008

69. Alldred MJ, Che S, Ginsberg SD: Terminal Continuation (TC) RNA amplification enables expression profiling using minute RNA input obtained from mouse brain. Int J Mol Sci 2008, 9:2091-2104.

70. Ginsberg SD: Transcriptional profiling of small samples in the central nervous system. Methods Mol Biol 2008, 439:147-158. doi:10.1186/1756-6606-3-34

Cite this article as: Devi et al:: Sex- and brain region-specific acceleration of $\beta$-amyloidogenesis following behavioral stress in a mouse model of Alzheimer's disease. Molecular Brain 2010 3:34.

\section{Submit your next manuscript to BioMed Central and take full advantage of:}

- Convenient online submission

- Thorough peer review

- No space constraints or color figure charges

- Immediate publication on acceptance

- Inclusion in PubMed, CAS, Scopus and Google Scholar

- Research which is freely available for redistribution 